\title{
Spyros Samaras, Scènes Orientales
}

\section{(2) OpenEdition}

\section{Journals}

Édition électronique

URL : https://journals.openedition.org/etudesbalkaniques/279

ISSN : 2102-5525

\section{Éditeur}

Association Pierre Belon

\section{Édition imprimée}

Date de publication : 1 janvier 2006

ISBN : 978-2-910-86006-6

ISSN : $1260-2116$

\section{Référence électronique}

«Spyros Samaras, Scènes Orientales », Études balkaniques [En ligne], 13 | 2006, mis en ligne le 01 septembre 2009, consulté le 22 juin 2021. URL : http://journals.openedition.org/etudesbalkaniques/ 279

Ce document a été généré automatiquement le 22 juin 2021.

Tous droits réservés 


\section{Spyros Samaras, Scènes Orientales}

1 Spyros Samaras, Scènes Orientales (Quatre suites caractéristiques pour piano à quatre mains).

Avec Natalia Miroshnikova et Alexis Miroshnikov (piano).

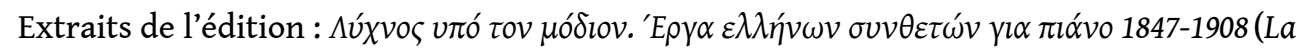

lampe sous le boisseau. CEuvres pour piano des compositeurs grecs 1847-1908), Presses Universitaires de Crète, Athènes 1999.

1. No. 1. Marche religieuse

2. No. 2. Danse

3. No. 3. Barcarolle

4. No. 4. Marche 